\title{
ADENOKARSINOMA PROSTAT: PENILAIAN PROGNOSTIK DAN DERAJAT HISTOPATOLOGI
}

\author{
Anandia Putriyuni, Noza Hilbertina
}

\begin{abstract}
Abstrak
Kanker prostat merupakan kanker kedua terbanyak pada pria di seluruh dunia. Tujuan penelitian ini adalah untuk mengetahui faktor prognostik adenokarsinoma prostat seperti derajat histopatologi berdasarkan the 2005 ISUP modified Gleason system, invasi perineural dan kadar PSA serum sebelum operasi. Ini adalah suatu penelitian deskriptif kasus adenokarsinoma prostat yang didiagnosis di laboratorium patologi anatomi periode 2010-2012. Data usia dan kadar PSA diperoleh dari rekam medik. Review sediaan histopatologi dilakukan untuk konfirmasi skor Gleason, lalu dikelompokan berdasarkan derajat histopatologi. Kasus adenokarsinoma prostat yang memenuhi kriteria inklusi adalah 163. Hasil penelitian menunjukkan kasus adenokarsinoma prostat terbanyak pada kelompok usia 61-70 tahun sebanyak $38,65 \%$, derajat histopatologi poorly differentiated yaitu $46,63 \%$, invasi perineural $22,7 \%$ dan $83,33 \%$ kadar PSA serum $>20$ $\mathrm{ng} / \mathrm{ml}$. Pada kelompok usia 51-60 tahun adenokarsinoma prostat terbanyak ditemukan dengan derajat histopatologi well differentiated; sedangkan kelompok usia 61-70 tahun, 71-80 tahun dan 81-90 tahun terbanyak poorly differentiated. Invasi perineural positif terbanyak pada derajat histopatologi poorly differentiated. Semua derajat histopatologi adenokarsinoma prostat menunjukkan kadar PSA serum terbanyak $>20 \mathrm{ng} / \mathrm{ml}$. Penelitian ini menunjukkan kecenderungan peningkatan usia, invasi perineural dan kasus dengan kadar PSA serum >20 $\mathrm{ng} / \mathrm{ml}$ bersamaan dengan peningkatan derajat histopatologi adenokarsinoma prostat.
\end{abstract}

Kata kunci: adenokarsinoma prostat, histopatologi, invasi perineural, kadar PSA serum

\begin{abstract}
Prostate cancer is the second most common cancer in men around the world. The objective of this study was to determine prognostic factors of prostate adenocarcinoma such as histopathological grading based on the 2005 ISUP modified Gleason system, perineural invasion, and PSA serum. This was a descriptive study of prostate adenocarcinoma diagnosed in Pathology Department from 2010 to 2012. The age and PSA serum level were taken from the medical records. The histological slides were reviewed to confirm Gleason score, and then classified into the histopathological grading. The number of prostate adenocarcinoma cases included in this study was 163. The result shows that the majority of cases were found at $61-70$ years old (38.65\%), histopathological grading was mostly poorly differentiated (46.63\%), positive perineural invasion $22.7 \%$ and $83.33 \%$ PSA serum above $20 \mathrm{ng} / \mathrm{ml}$. Prostate adenocarcinomas found at age 51-60 years old were mostly well differentiated. On the other hand, cases found at age above 60 years old were mostly poorly differentiated. Perineural invasion was mostly found on poorly differentiated cases. All of histopathological grading showed PSA serum above 20 $\mathrm{ng} / \mathrm{ml}$. This study suggested that higher age, perineural invasion and PSA serum level above 20 $\mathrm{ng} / \mathrm{ml}$ were congruent with the histopathological grading.
\end{abstract}

Keywords: prostate adenocarcinoma, histopathological, perineural invasion, PSA serum level

Afiliasi Penulis : Bagian Patologi Anatomi Fakultas Kedokteran Universitas Andalas, Korespondensi: Anandia Putriyuni, Bagian Patologi Anatomi Fakultas Kedokteran Universitas Andalas, Jl. Perintis Kemerdekaan No.94 Padang PO BOX 49,email : anandia_putriyuni@yahoo.com , Telp \HP: 08126619832 


\section{PENDAHULUAN}

Kanker prostat merupakan kanker ke-2 terbanyak yang didiagnosis pada laki-laki di seluruh dunia dan urutan ke-5 kanker terbanyak dari seluruh kanker pada tahun 2008 dalam penelitian kanker internasional pada 182 negara. Insiden di berbagai negara bervariasi, yang tertinggi adalah Australia / Selandia Baru (100,42 per 100.000), Eropa Barat dan Utara serta Amerika Utara, sedangkan insiden terendah di Asia Selatan (4,1 per 100.000). ${ }^{1,2}$

Kanker prostat menduduki urutan ke-1 dari 10 tumor primer tersering pada laki-laki di Indonesia, berdasarkan data histopatologik Badan Registrasi Kanker IAPI dan Departemen Kesehatan RI tahun 2009. Urutan tersebut meningkat dari tahun sebelumnya pada urutan ke-2 setelah kanker nasofaring. Kasus kanker prostat di Padang tahun 2009 dilaporkan sebanyak 85 kasus yang menempati urutan ke-1 dari 10 tumor primer tersering pada laki-laki. Tahun sebelumnya tercatat sebanyak 61 kasus, menempati urutan ke-3. 3,4

Banyaknya variasi dalam masingmasing gambaran pola Gleason yang asli menyebabkan perbedaan inter dan intraobserver dalam menentukan skor Gleason. ${ }^{5-7}$ Untuk mendapatkan kesepakatan dalam menerapkan sistem Gleason tersebut, the International Society of Urological Pathology (ISUP) tahun 2005 menghasilkan The 2005 ISUP Modified Gleason System. ${ }^{8}$ Saat ini belum tersedia data kanker prostat dengan gambaran histopatologi berdasarkan sistem Gleason yang terbaru dari laboratorium Patologi Anatomi yang ada di wilayah Sumatera Barat.
Berdasarkan uraian dalam latar belakang di atas, maka tujuan penelitian ini untuk mengetahui faktor-faktor prognostik adenokarsinoma prostat diantaranya derajat histopatologi berdasarkan sistem Gleason ISUP 2005 yang telah dimo-difikasi, invasi perineural dan kadar PSA serum sebelum operasi.

\section{METODE}

Penelitian ini merupakan penelitian deskriptif observasional. Populasi penelitian adalah kasus adenokarsinoma prostat yang telah didiagnosis di Laboratorium Patologi Anatomi yang berada di wilayah Sumatera Barat yaitu FK Unand, RS M. Djamil Padang, RSI Ibnu Sina Padang, RSI Siti Rahmah Padang dan RS Achmad Mochtar Bukittinggi periode tahun 2010-2012. Subjek penelitian adalah semua populasi yang sudah memenuhi kriteria inklusi dan eksklusi. Kriteria inklusi adalah kasus adenokarsinoma prostat yang data lengkap kecuali kadar PSA serum sebelum operasi. Kriteria eksklusi adalah kasus adenokarsinoma prostat yang tidak dapat dilakukan review terkait kondisi sediaan hapus atau blok parafinnya.

Data penelitian berupa usia dan kadar PSA sebelum operasi diambil dari blanko pemeriksaan pasien. Kasus adenokarsinoma prostat yang telah didiagnosis dilakukan review sediaan hapus $\mathrm{HE}$ dengan mikroskop cahaya binokuler. Penetapan skor Gleason berdasarkan The 2005 ISUP Modified Gleason System yang kemudian dikelompokkan dalam derajat histopatologi yaitu well differentiated (Gleason $\leq 6)$, moderately differentiated (Gleason 7), poorly differentiated/ undifferentiated (Gleason 8-10). Invasi 
perineural ditentukan berdasarkan gambaran sel tumor yang tumbuh mengelilingi saraf secara komplit (invasi perineural sirkumferensial).

\section{HASIL DAN PEMBAHASAN}

Pada penelitian ini didapatkan sampel sebanyak 163 kasus adenokarsinoma prostat yang memenuhi kriteria inklusi dari 173 populasi di semua laboratorium Patologi Anatomi Sumatera Barat tahun 2010-2012, sedangkan data kadar PSA serum sebelum operasi ditemukan hanya 36 kasus. Jumlah kasus terbanyak adalah kelompok usia 61-70 tahun yaitu 63 kasus (38,65\%). Kelompok usia kurang dan sama dengan 50 tahun ditemukan hanya 3 kasus $(1,84 \%)$ dalam tabel 1. Pasien dengan usia paling muda yang didiagnosis adenokarsinoma prostat adalah 38 tahun dan usia paling tua 90 tahun. Hasil penelitian ini sesuai dengan beberapa kepustakaan dan penelitian lain. Kanker prostat menurut data dari Surveillance, Epidemiology and End Result (SEER) paling sering ditemukan pada usia rata-rata 67,2 tahun pada 2004-2005. ${ }^{1}$ Penelitian Rulli dkk (2011) di RS M. Djamil Padang tahun 2003-2010 mendapatkan adenokarsinoma prostat sebanyak 238 kasus dengan kelompok usia terbanyak 61-70 tahun. $^{9}$ Junaidi (2012) menemukan usia rata-rata pasien 65,3 tahun dengan kelompok usia terbanyak adalah 56-60 tahun dari 33 kasus adenokarsinoma prostat yang diperiksa di RS Adam Malik Medan periode Juli 2010-Juni 2012. ${ }^{10}$ Penelitian Sigh dkk (2011) terhadap 148 pasien adenokarsinoma prostat pada Juni 2006 sampai Oktober 2009 didapatkan usia rata-rata 64 tahun dengan kelompok usia terbanyak 50-76 tahun. ${ }^{11}$
Tabel 1. Karakteristik Adenokarsinoma Prostat di Laboratorium Patologi Anatomi Sumatera Barat tahun 2010-2012

\begin{tabular}{|c|c|c|}
\hline Karakteristik & $F$ & $\%$ \\
\hline \multicolumn{3}{|l|}{ KelompokUsia (tahun) } \\
\hline$\leq 50$ & 3 & 1,84 \\
\hline $51-60$ & 21 & 12,88 \\
\hline $61-70$ & 63 & 38,65 \\
\hline $71-80$ & 60 & 36,81 \\
\hline $81-90$ & 16 & 9,82 \\
\hline \multicolumn{3}{|l|}{ Derajat Histopatologi } \\
\hline Well Differentiated (Gleason $\leq 6)$ & 41 & 25,15 \\
\hline Moderately Differentiated(Gleason 7) & 46 & 28,22 \\
\hline Poorly Differentiated/Undifferentiated (Gleason 8-10) & 76 & 46,63 \\
\hline \multicolumn{3}{|l|}{ Invasi Perineural } \\
\hline Positif & 37 & 22,70 \\
\hline Negatif & 126 & 77,30 \\
\hline \multicolumn{3}{|l|}{ Kadar PSA Serum Sebelum Op (ng/ml) } \\
\hline$<10$ & 5 & 13,89 \\
\hline $10-20$ & 1 & 2,78 \\
\hline$>20$ & 30 & 83,33 \\
\hline
\end{tabular}

Derajat histopatologi dinilai berdasarkan sistem Gleason ISUP 2005 yang merupakan modifikasi dari sistem yang asli dan kemudian direvisi terutama pada pola 3 dan 4. Penderajatan ini berdasarkan kelompokan skor Gleason yang telah ditetapkan dan diaplikasikan oleh klinisi seperti Ikatan Ahli Urologi Indonesia dan National Comprehensive Cancer Network. ${ }^{12,13}$ Tingkatan derajat histopatologi tersebut adalah well differentiated (Gleason $\leq 6)$, moderately differentiated (Gleason 7) dan poorly differentiated/ undifferentiated (Gleason 8 - 10). Pada penelitian ini didapatkan derajat histopatologi terbanyak adalah poorly differentiated/ undifferentiated dengan jumlah 76 kasus (46,63\%), terutama skor Gleason 9 dan 8. Kemudian diikuti dengan moderately differentiated sebanyak 
46 kasus $(28,22 \%)$ dan well differentiated 41 kasus $(25,15 \%)$,dalam tabel 1.

Berbeda dengan penelitian Singh dkk yang mendapatkan skor Gleason 6 terbanyak yaitu 75 kasus (50,5\%), diikuti dengan Gleason 7 sebanyak 33 kasus $(22,2 \%)$, sedangkan Gleason $8-10$ sebanyak 18 kasus $(12,1 \%) .{ }^{11}$ Penelitian Junaidi juga menemukan adenokarsinoma prostat terbanyak dengan skor Gleason 6 (33,3\%), kemudian Gleason 4 $(30,1 \%), \quad 5 \quad(15,2 \%)$ dan $7 \quad(9,1 \%)$, sedangkan skor Gleason 8 dan 9 masingmasing hanya 2 (6,1\%). ${ }^{10}$ Penelitian Jackson dkk (2012) mendapatkan dari 221 kasus pada tahun 2011 ditemukan skor Gleason 6 terbanyak yaitu 78 kasus $(35,29 \%)$, diikuti Gleason 7 sebanyak 76 kasus (34,39\%), Gleason 8 kasus $(16,74 \%)$, Gleason 9 sebanyak 29 kasus $(13,12 \%)$ dan Gleason 10 hanya 1 kasus $(0,46 \%) .{ }^{14}$ Wadgaonkar dkk (2013) mendapatkan kasus terbanyak dengan skor Gleason 7 sebanyak 6 kasus $(54,5 \%), 3$ kasus $(27,3 \%)$ dengan skor Gleason 8 dan 1 kasus dengan skor Gleason $9-10 .{ }^{15}$

Perbedaan hasil ini mungkin disebabkan oleh perbedaan dalam sistem Gleason yang digunakan, sehingga berbeda dalam menetapkan pola Gleason terutama pola 3 dan 4. Pada penelitian ini digunakan sistem Gleason ISUP 2005 yang telah direvisi berdasarkan beberapa kepustakaan terbaru. Junaidi menggunakan sistem Gleason ISUP 2005 yang belum direvisi, ${ }^{10}$ Wadgaonkar dkk menggunakan sistem Gleason yang asli dan penelitian lainnya tidak menjelaskan sistem Gleason yang digunakan. ${ }^{15}$ Modifikasi sistem Gleason yang asli dengan sistem Gleason ISUP 2005 bertujuan untuk mengurangi variasi interobserver dan menyebabkan rata-rata skor Gleason yang lebih tinggi meningkat dalam beberapa penelitian. ${ }^{16}$

Penelitian Fang dkk (2013) pada 75 pasien yang didiagnosis adenokarsinoma prostat pada bulan Mei 2005-Mei 2009. Penelitian tersebut menggunakan pengelompokan histopatologi well differentiated (Gleason 2-5), moderately differentiated (Gleason 6-7) dan poorly differentiated (Gleason 8-10). Dari 75 kasus tersebut ditemukan skor Gleason terbanyak adalah skor 2-5 sebanyak 48 kasus, diikuti skor 8-10 sebanyak 16 kasus kemudian skor 6-7 sebanyak 11 kasus.

Tabel 2. Distribusi Frekuensi Derajat Histopatologi Adenokarsinoma Prostat Berdasarkan Kelompok Usia

\begin{tabular}{ccccc}
\hline Kelompok & \multicolumn{3}{c}{ Derajat Histopatologi } & \\
\cline { 2 - 4 } Usia & Well & Moderately & Poorly Diffl & Total \\
(tahun) & $f(\%)$ & $f(\%)$ & $f(\%)$ & $f(\%)$ \\
\hline$\leq 50$ & $1(33,33)$ & $1(33,33)$ & $1(33,33)$ & $3(100)$ \\
$51-60$ & $9(42,86)$ & $6(28,57)$ & $6(28,57)$ & $21(100)$ \\
$61-70$ & $14(22,22)$ & $20(31,75)$ & $29(46,03)$ & $63(100)$ \\
$71-80$ & $16(26,67)$ & $14(23,33)$ & $30(50)$ & $60(100)$ \\
$81-90$ & $1(6,25)$ & $5(31,25)$ & $10(62,50)$ & $16(100)$ \\
\hline
\end{tabular}

Tabel 2 menunjukkan bahwa persentase terbanyak derajat histopatologi poorly differentiated (skor Gleason 8-10) ditemukan pada kelompok usia 81-90 tahun sebanyak $62,50 \%$, kemudian diikuti dengan kelompok usia 71-80 tahun sebanyak $50 \%$. Hal ini menunjukkan bahwa semakin meningkat usia penderita cenderung semakin banyak kasus adenokarsinoma prostat dengan derajat histopatologi poorly differentiated/ undifferentiated.

Invasi perineural didefinisikan sebagai pertumbuhan sel tumor yang mengelilingi saraf secara komplit yang disebut 
juga invasi perineural sirkumferensial. ${ }^{18}$ Invasi perineural sering ditemukan pada adenokarsinoma prostat. Penemuan invasi perineural menjadi bukti yang dianggap kuat pada keganasan tetapi tidak ditemukan pada lesi jinak. Invasi perineural merupakan gambaran patognomonik untuk diagnosis adeno karsinoma prostat berdasarkan survei patologi genitourinari tahun 2006. Invasi perineural menjadi salah satu faktor prognostik kanker prostat. ${ }^{5,19}$

Pada penelitian ini ditemukan 37 kasus positif invasi perineural dari semua derajat histopatologi. Persentase invasi perineural yang positif paling banyak ditemukan pada derajat histopatologi poorly differentiated/ undifferentiated (Gleason 8-10) sebanyak 31,58\% dibandingkan moderately differentiated $(19,57 \%)$ dan well differentiated $(9,76 \%)$ (Tabel 3). Hasil penelitian ini menunjuk kan adanya kecenderungan peningkatan persentase positif invasi perineural bersamaan dengan peningkatan derajat histopatologi adenokarsinoma prostat. Kasus positif invasi perineural diperoleh dari tindakan Open Prostatectomy, Transurethral Prostatectomy (TURP) dan biopsi.

Tabel 3. Distribusi Frekuensi Invasi

Perineural Berdasarkan Derajat Histopatologi Adenokarsinoma Prostat

\begin{tabular}{lccc}
\hline \multirow{1}{*}{ Derajat Histopatologi } & \multicolumn{2}{c}{ Invasi Perineural } & \\
\cline { 2 - 3 } & $\begin{array}{c}\text { Positif } \\
f(\%)\end{array}$ & $\begin{array}{c}\text { Negatif } \\
f(\%)\end{array}$ & $\begin{array}{c}\text { Total } \\
f(\%)\end{array}$ \\
\hline $\begin{array}{l}\text { Well Differentiated (Gleason } \leq 6) \\
\text { Moderately Differentiated }\end{array}$ & $4(9,76)$ & $37(90,24)$ & $41(100)$ \\
$\begin{array}{l}\text { (Gleason 7) } \\
\text { Poorly }\end{array}$ & $9(19,57)$ & $37(80,43)$ & $46(100)$ \\
$\begin{array}{l}\text { Differentiated/Undifferentiated } \\
\text { (Gleason 8-10) }\end{array}$ & $24(31,58)$ & $52(68,42)$ & $76(100)$ \\
\hline
\end{tabular}

Penelitian Singh dkk pada kasus adenokarsinoma prostat dari tindakan radikal prostatektomi robotik menemukan invasi perineural sebanyak 30 (20,2\%) kasus dari 148 kasus yang diteliti. ${ }^{11}$ Jackson dkk menemukan invasi perineural pada 15 kasus (6,79\%) dan tidak menginvasi sebanyak 206 kasus $(93,21 \%)$ dari sampel biopsi yang dituntun dengan Transrectal Ultrasonography(TRUS). ${ }^{14}$ Wadgaonkar dkk yang mengambil sampel dari tindakan TURP, biopsi dan open prostatectomy menemukan hanya 2 kasus yang mengalami invasi perineural dari 11 kasus adenokarsinoma prostat. $^{15}$ Ketiga penelitian tersebut tidak menghubungkan dengan derajat histopatologi adenokarsinoma prostat.

Gambaran invasi perineural sering menunjukkan suatu jalur perluasan di luar prostat karena sel-sel tumor sering menyebar di sepanjang bundel saraf untuk mencapai jaringan di luar prostat khususnya di bagian posterior atau lateral dari daerah bundel neuro-vaskular. ${ }^{6}$ Mekanisme invasi perineural tidak diketahui sampai saat ini, tetapi beberapa penemuan menunjukkan adanya interaksi antara sel tumor dengan saraf. Pada penelitian Li dkk, Neural Cell Adhesion Molecule(N-CAM) yang merupakan salah satu molekul adhesi yang diekspresikan pada $73 \%$ saraf yang mengalami invasi perineural dibandingkan dengan saraf tanpa gambaran invasi. $\mathrm{Hal}$ ini menunjukkan bahwa N-CAM mungkin terlibat dalam fenomena ini pada kanker prostat. ${ }^{18}$

Faktor prognostik kanker prostat lainnya adalah kadar PSA serum sebelum operasi. Faktor ini merupakan parameter diagnostik dan prognostik 
untuk kanker prostat, semakin tinggi kadar PSA serum maka semakin tinggi pula kecurigaan adanya kanker prostat. Nilai baku PSA serum di Indonesia yang dipakai saat ini adalah $4 \mathrm{ng} / \mathrm{ml} .{ }^{12} P a d a$ penelitian ini data kadar PSA serum sebelum operasi didapatkan sebanyak 36 kasus pada adenokarsinoma prostat, karena tidak semua kasus diperiksakan dengan berbagai alasan. Tabel 4 menunjukkan bahwa persentase kadar PSA serum sebelum operasi $>20 \mathrm{ng} / \mathrm{ml}$ ditemukan paling banyak pada derajat histopatologi poorly differentiated/ undifferentiated $(87,50 \%)$. Dalam penelitian ini ditemukan 1 kasus adenokarsinoma prostat dengan kadar PSA serum sebelum operasi yang dibawah nilai baku yaitu $<4 \mathrm{ng} / \mathrm{ml}$ pada derajat histopatologi moderately differentiated. Hasil ini menunjukkan kecenderungan peningkatan persentase kasus dengan kadar PSA serum sebelum operasi > $20 \mathrm{ng} / \mathrm{ml}$ seiring dengan peningkatan derajat histopatologi adenokarsinoma prostat.

Tabel 4.Distribusi Frekuensi Kadar PSA Serum Sebelum Operasi Berdasarkan Derajat Histopatologi Adenokarsinoma Prostat

\begin{tabular}{lcccc}
\hline \multirow{3}{*}{ Derajat Histopatologi } & \multicolumn{4}{c}{ Kadar PSA Serum (ng/ml) } \\
\cline { 2 - 4 } & $\langle 10$ & $10-20$ & $>20$ & Total \\
& $f(\%)$ & $f(\%)$ & $f(\%)$ & $f(\%)$ \\
\hline Well Diff(Gleason S6) & $1(20)$ & $1(20)$ & $3(60)$ & $5(100)$ \\
Moderately Diff (Gleason 7) & $1(14,29)$ & $0(0)$ & $6(85,71)$ & $7(100)$ \\
Poorly Diff/Undiff(Gleason 8-10) & $3(12,50)$ & $0(0)$ & $21(87,50)$ & $24(100)$
\end{tabular}

Hasil penelitian ini hampir sama dengan penelitian Fang dkk yang menemukan hubungan yang positif antara kadar PSA serum sebelum operasi dengan skor Gleason. Pasien dengan kadar PSA > $20 \mathrm{ng} / \mathrm{ml}$ memiliki proporsi lebih tinggi secara signifikan pada skor
Gleason 8-10 dibandingkan kadar PSA $\leq$ 20 ng/ml. ${ }^{17}$ Junaidi menemukan kadar PSA serum terbanyak adalah 6-15 $\mathrm{ng} / \mathrm{ml}$, tetapi ditemukan adanya hubungan yang signifikan antara kadar PSA serum dengan derajat histopatologi menurut sistem Gleason. ${ }^{10}$ Begitu pula dengan Jackson dkk yang menemukan kadar PSA serum meningkat bersamaan dengan skor Gleason, dengan kadar PSA >20 ng/ml ditemukan paling banyak pada skor Gleason 9. ${ }^{14}$ Penelitian Okolo dkk (2008) juga menemukan kecenderungan peningkatan kadar PSA serum sebelum operasi dengan peningkatan derajat histopatologi, secara statistik menunjukkan hubungan yang positif. ${ }^{20}$ Singh dkk menemukan kadar PSA serum sebelum operasi yang terbanyak 4,1-10 $\mathrm{ng} / \mathrm{ml}$ yaitu 50 kasus (34\%), diikuti dengan kadar >20 ng/ml sebanyak 46 kasus (31,1\%), kadar 10,1$20 \mathrm{ng} / \mathrm{ml}$ sebanyak 41 kasus $(27,7 \%)$ dan kadar $<4 \mathrm{ng} / \mathrm{ml}$ sebanyak 11 kasus $(7,4 \%) .^{11}$

Dari kepustakaan dijelaskan bahwa saat kanker prostat berkembang menyebabkan volume jaringan tumor bertambah sehingga jaringan tumor menjadi semakin tidak teratur dan skor Gleason juga ikut meningkat. Pertumbuhan kelenjar tidak beraturan, lumen kelenjar tidak terbentuk dan komponen matriks berkurang. Sekresi PSA oleh sel kanker juga meningkat bersamaan dengan barier antara lapisan sel basal dan membran basalis yang rusak berat. Sebagai tambahan, angiogenesis juga aktif pada saat yang sama, sehingga pada akhirnya mengakibatkan bocornya PSA ke dalam sirkulasi dan terjadi peningkatan kadar PSA serum. Hal ini mungkin menjadi salah satu alasan mengapa kadar PSA serum memiliki 
hubungan yang positif dengan skor Gleason. ${ }^{17}$

\section{SIMPULAN}

Adenokarsinoma prostat terbanyak ditemukan pada kelompok usia 61-70 tahun, derajat histopatologi terbanyak adalah poorly differentiated (skor Gleason 8-10) dan kadar PSA serum sebelum operasi terbanyak pada kadar $>20 \mathrm{ng} / \mathrm{ml}$. Invasi perineural yang positif ditemukan pada sepertiga dari sampel. Kelompok usia 51-60 tahun paling banyak ditemukan pada derajat well differentiated, sedangkan kelompok usia 61-70 tahun, 71-80 tahun dan 81-90 tahun paling banyak dengan derajat poorly differentiated. Invasi perineural yang positif lebih banyak ditemukan pada adenokarsinoma prostat dengan derajat poorly differentiated.

Semua derajat histopatologi adenokarsinoma prostat menunjukkan kadar PSA serum sebelum operasi terbanyak yaitu $>20 \mathrm{ng} / \mathrm{ml}$. Penelitian ini juga menunjukkan kecenderungan peningkatan usia, persentase positif invasi perineural dan persentase kasus dengan kadar PSA serum >20 ng/ml bersamaan dengan peningkatan derajat histopatologi adenokarsinoma prostat.

\section{DAFTAR RUJUKAN}

1. Jeong IG, Kim CS, Ro JY. Introduction and prostate cancer statistic. In Ro JY, Shen SS, Zhai QJ, Ayala AG, editors. Advances in Surgical Pathology Prostate Cancer. Philadelphia; Lippincott Williams \& Wilkins 2012:3-7.

2. Miocinovic R. Epidemiology and risk factor. In Klein EA, Jones JS, editors. Management of Prostate Cancer. $3^{\text {th }}$ Ed. New York: Humana Press 2013:1-12.
3. Badan Registrasi Kanker IAPI. Direktorat Jenderal Pelayanan Medik Departemen Kesehatan Republik Indonesia. Kanker di Indonesia tahun 2008 data histopatologik. Jakarta; Yayasan Kanker Indonesia2008.

4. Badan Registrasi Kanker IAPI. Direktorat Jenderal Pelayanan Medik Departemen Kesehatan RI. Kanker di Indonesia tahun 2009 data histopatologi. Jakarta; Yayasan Kanker Indonesia2009.

5. Bostwick DG, Meiers I. Prostate. In Weidner N, Cote RJ, Suster S, Weiss LM, editors. Modern Surgical Pathology. $2^{\text {nd }} E d$. Philadelphia; Saunders Elsevier2009: 112180.

6. Divatia M, Shen SS, Ro JY. Gleason grading system. In Ro JY, Shen SS, Zhai QJ, Ayala AG, editors. Advances in Surgical Pathology Prostate Cancer. Philadelphia; Lippincott Williams \& Wilkins 2012:142-56.

7. Osunkoya AO. Update on prostate pathology. Pathology. 2012;44(5): 391-406.

8. Evegad L, Mazzucchchelli R, Montironi R. Implications of the international society of urological pathology modified Gleason grading system, Arch Pathol Lab Med.2012;136:426-34.

9. Rulli, Zulfiqar $Y$, Alvarino, Efman-syah D. Gambaran karsinoma prostat di laboratorium Patologi Anatomi RS M Djamil Padang periode 2003-2010. Prosiding PIT IKABI XVIII; Jakarta Indonesia 30 Juni-2 Juli 2011.

10. Junaidi F. Hubungan antara grading histopatologi (Gleason score) dan level PSA kanker prostat di Rumah Sakit Umum Pusat H. Adam Malik-Medan (tesis). Medan: Universitas Sumatera Utara; 2012.

11. Singh P, Dogra PN, Gupta NP, Seth A, Javali TD, Kumar R. Correlation between the preoperative serum prostate specific antigen, Gleason score, and clinical staging with pathological outcome following robot-assisted radical prostatectomy. Indian $\mathrm{J}$ Cancer. 2011;28(4):483-7.

12. Ikatan Ahli Urologi Indonesia. Panduan penatalaksanaan kanker prostat 2011. Jakarta.

13. National Comprehensive Cancer Network. NCCN clinical practice guidelines in oncology prostate cancer. $3^{\text {th }}$ Ed. National Comprehensive Cancer Network Inc 2012. 
14. Jackson LA, McGrowder DA, Lindo RA. Prostate specific antigen and Gleason score in men with prostate cancer at a private diagnostic radiology centre in Western Jamaica. Asian Pac J Cancer Prev. 2012;13:1453-6.

15. Wadgaonkar AR, Patil AA, Mahajan SV, Yengantiwar RP. Correlation of serum prostate specific antigen (PSA) level in various prostate pathology in elderly men. Int J Basic Appl Med Sc. 2013;3(2):274-81.

16. Iczkowski KA, Lucia MS. Current perspective on Gleason Grading of Prostate cancer. Curr Urol Rep. 2011;12(3):216-22.

17. Fang YQ, Zhou XF, Qiu JG et al. Serum PSA level and Gleason scores of needle biopsy specimens predict the postoperative pathologic grade of prostate cancer. Acta Medica Mediterr. 2013;29:279-83.
18. Pina-Oviedo S, Ayala AG, Ro JY. Histopathology of prostate cancer. In Ro JY, Shen SS, Zhai QJ, Ayala AG, editors. Advances in Surgical Pathology Prostate Cancer. Philadelphia: Lippincott Williams \& Wilkins; 2012. p.121-41.

19. Martin NE, Lorelei AM, Loda ML, et al. Prognostic determinants in prostate cancer. Cancer J. 2011;17(6):429-37.

20. Okolo CA, Akinosun OM, Shittu OB, et al. Correlation of serum PSA and Gleason score in Nigerian men with prostate cancer. African J Uro. 2008;14(1):15-22. 